\title{
Cereal Residues - Not a Waste Until We Waste it: A Review
}

\author{
Amit Anil Shahane and Yashbir Singh Shivay*
}

Division of Agronomy, ICAR-Indian Agricultural Research Institute, New Delhi (110 012), India

\section{Article History}

Manuscript No. AR1401b

Received in $10^{\text {th }}$ July, 2015

Received in revised form $25^{\text {th }}$ January, 2016

Accepted in final form $4^{\text {th }}$ February, 2016

\section{Correspondence to}

${ }^{*}$ E-mail: ysshivay@hotmail.com

\section{Keywords}

Cereal residue, ecological services, energy source, residue burning

\begin{abstract}
Residue generated along with economic plant part in cereal crops is voluminous. Management and effective utilization of residue for productive purpose is of prime importance in all major cereal growing area. In India about $416.5 \mathrm{mt}$ of crop residue is generated from five major cereals (rice, wheat, maize, sorghum and pearl millet) in the year 2011-12. The management of residue is a major challenge in intensive cerealbased cropping systems where two or more cereals are grown in a single year. This is mainly due to low turn-around period and less preference as animal feed. The burden of managing bulky residue leads to adoption of easy but ecologically harmful ways like on-farm burning. On the other hand, the potential of cereal residue to contribute plant nutrient and carbon content along with various economic useful purposes need to be taken into account while managing it. In present review, we have discussed the residue potential, options for residue management with their pros and cons and research findings and research needs for effective utilization of residue under the following heads: 1) Potential of residue generation in India; 2) Options for utilization of generated residue; 3) Criteria for evaluation of residue management option; 4) Factor influencing selection of management option; 5) Residue management in reference to dry land agriculture; 6) Research, development and policy needs in residue management and 7) Model plan for residue management in Indian condition. In nutshell, our review emphasise management and efficient utilization of cereal residue, which leads to winwin situation for both environment and farmers.
\end{abstract}

\section{Introduction}

'Necessity is the mother of invention' and human evolution is the evidence to prove this quotation. Over the period of time during evolution, as our necessities increases, we used to search things in the environment around us to get fulfil these needs. With regards to arable crops especially cereals, human beings are mainly concerns with the some parts of plant which have saleable value owing to their use for different purposes. We categorise these plant parts as 'economic plant parts'. Increase in understanding about agriculture along with development and also due to increasing pressure of population, we are supposed to bring those plant parts for use which we previously not used at all and that is crop residue.

Crop residue is defined as any plant part remained after economic part of plant has been separated out. Crop residues may be categorized as: a) those include materials left in agriculture field after harvesting of crop (field crop residue) which include stalks and stubble in case of cereals; b) processed residue which comprised materials left after the crop is processed into a usable resource. It includes husk or hull in case of cereals and bagasse and molasses in case of sugarcane. Sometimes definition of crop residue is restricted to above-ground plant parts. Root mass also adds organic matter but their quantity is insignificant and also quantification of biomass added by them is cumbersome. That is the reason for non- accountability of root biomass most of the time while calculating residue generation potential. Ratio of shoot dry weight to root dry weight is also found useful for calculation of root biomass. Residue production is basically a function of total biomass production and the harvest index. Crop biomass production is determined by the biophysical environment, including defining, limiting and reducing conditions (Rabbinge and van Ittersum, 1994). Crop attributes are an important defining condition (e.g. a cereal crop potentially produces more biomass than a leguminous crop) (Erenstein, 2002). Residue is also called as 'economic product of second order' owing to realization of potential to be used for a variety of purpose in general and use in energy generation in addition to source 
and sink for carbon particularly in today's world. Considering potential of residue one can say, agriculture is not only way of life for achieving food security and minimizing malnutrition through main produce (food-grains, fruits and vegetables), but it may also be an important solution to other issues like declining fertility, erosion and global warming through efficient management of crop residue.

\section{Potential of Residue Generation in India}

India produced a record of $257.4 \mathrm{mt}$ of food-grains in 201112 along with production of more than $500 \mathrm{mt}$ crop residues annually (NAAS, 2012). An estimate shows that, annually about $525 \mathrm{mt}$ crop residues are available in India, out of which about $125 \mathrm{mt}$ are surplus (Pathak, 2004). According to Beri et al. (2002), $462.9 \mathrm{mt}$ of residues from major crops are available annually in India. There is large variation in estimated amount of residue generation and actual residue produced as production of residue is affected by number of factors and is not only the function of ratio of economic produce to total biomass produced. Ministry of New and Renewable Energy (2009), Government of India estimated that, among different crops, cereals, fibres, oilseed, pulses and sugarcane crop generate 352 , 66, 29, 13 and $12 \mathrm{mt}$ residues, respectively (Figure 1a). The cereal crops rice (Oryza sativa L.), wheat (Triticum aestivum L.), maize (Zea mays L.) and millets contribute $70 \%$; while rice and wheat contributes $34 \%$ and $22 \%$ to total residues generated from all crops. Contribution of rice and wheat to the total residue generated is $51 \%$ and $27 \%$ respectively as estimated by Lal and Kimble (2002). This indicates that cereals have major share in crop residue generation in India.

The surplus residues, i.e., balance between total residues generated and residues used for various purposes, are typically burned in the field or used to meet household energy needs by farmers. Estimated total crop residue surplus in India is 84-141 mt year ${ }^{-1}$ where cereals and fibre crops contribute $58 \%$ and $23 \%$ respectively (Figure $1 \mathrm{~b}$ ). Out of $82 \mathrm{mt}$ surplus residues from the cereal crops, $44 \mathrm{mt}$ is from rice followed by $24.5 \mathrm{mt}$ of wheat. On comparison of different states of India for their residue generation potential, there is large variation among states regarding residue generation potential and surplus amount of residue (Table 1). This variability in generation of crop residues and their use is depending on the cropping intensity, productivity and crops grown among different states of India.

Uttar Pradesh rank first in total residue generation (59.97 $\mathrm{mt}$ ) followed by Punjab (50.75 mt); While in surplus, Punjab ranks first with surplus of $24.83 \mathrm{mt}$ of residue followed by Maharashtra $(14.67 \mathrm{mt})$. Haryana which is at tenth position in generation of residue ranks fourth position in surplus. Pathak et al. (2010) reported that, Uttar Pradesh, Punjab and Haryana are the three major states where residue burning is practiced and these three states accounts about $52.7 \mathrm{mt}(56.8 \%)$ of residue burned out of total residue burned (92.81 mt) in India.

Table 1: State-wise quantification of generation, surplus and burning of crop residue in different states of India

\begin{tabular}{|c|c|c|c|c|c|}
\hline $\begin{array}{l}\text { Sr. } \\
\text { no. }\end{array}$ & State & $\begin{array}{c}\text { Crop } \\
\text { residue } \\
\text { generation } \\
\left(\mathrm{mt} \mathrm{yr}^{-1}\right)\end{array}$ & $\begin{array}{l}\text { Crop } \\
\text { residue } \\
\text { surplus } \\
(\mathrm{mt} \\
\left.\mathrm{yr}^{-1}\right)\end{array}$ & $\begin{array}{c}\text { Crop } \\
\text { residue } \\
\text { burnt } \\
(\mathrm{mt} \\
\left.\mathrm{yr}^{-1}\right)\end{array}$ & $\begin{array}{c}\text { Crop residue } \\
\text { burnt } \\
\text { (based on } \\
\text { IPCC coef- } \\
\text { ficients) (mt } \\
\mathrm{yr}^{-1} \text { ) }\end{array}$ \\
\hline 1. & $\begin{array}{l}\text { Andhra } \\
\text { Pradesh }\end{array}$ & 43.89 & 6.96 & 2.73 & 6.46 \\
\hline 2. & $\begin{array}{l}\text { Arunachal } \\
\text { Pradesh }\end{array}$ & 0.40 & 0.07 & 0.04 & 0.06 \\
\hline 3. & Asom & 11.43 & 2.34 & 0.73 & 1.42 \\
\hline 4. & Bihar & 25.29 & 5.08 & 3.19 & 3.77 \\
\hline 5. & Chhattisgarh & 11.25 & 2.12 & 0.83 & 1.84 \\
\hline 6. & Goa & 0.57 & 0.14 & 0.04 & 0.08 \\
\hline 7. & Gujarat & 28.73 & 8.9 & 3.81 & 9.64 \\
\hline 8. & Haryana & 27.83 & 11.22 & 9.06 & 6.06 \\
\hline 9. & $\begin{array}{l}\text { Himachal } \\
\text { Pradesh }\end{array}$ & 2.85 & 1.03 & 0.41 & 0.20 \\
\hline 10. & $\begin{array}{l}\text { Jammu \& } \\
\text { Kashmir }\end{array}$ & 1.59 & 0.28 & 0.89 & 0.35 \\
\hline 11. & Jharkhand & 3.61 & 0.89 & 1.10 & 1.11 \\
\hline 12. & Karnataka & 33.94 & 8.98 & 5.66 & 3.05 \\
\hline 13. & Kerala & 9.74 & 5.07 & 0.22 & 0.40 \\
\hline 14. & $\begin{array}{l}\text { Madhya } \\
\text { Pradesh }\end{array}$ & 33.18 & 10.22 & 1.91 & 3.74 \\
\hline 15. & Maharashtra & 46.45 & 14.67 & 7.41 & 7.82 \\
\hline 16. & Manipur & 0.90 & 0.11 & 0.07 & 0.14 \\
\hline 17. & Meghalaya & 0.51 & 0.09 & 0.05 & 0.10 \\
\hline 18. & Mizoram & 0.06 & 0.01 & 0.01 & 0.02 \\
\hline 19. & Nagaland & 0.49 & 0.09 & 0.08 & 0.11 \\
\hline 20. & Odisha & 20.07 & 3.68 & 1.34 & 2.61 \\
\hline 21. & Punjab & 50.75 & 24.83 & 19.62 & 9.84 \\
\hline 22. & Rajasthan & 29.32 & 8.52 & 1.78 & 3.84 \\
\hline 23. & Sikkim & 0.15 & 0.02 & 0.01 & 0.01 \\
\hline 24. & Tamil Nadu & 19.93 & 7.05 & 4.08 & 3.62 \\
\hline 25. & Tripura & 0.04 & 0.02 & 0.11 & 0.22 \\
\hline 26. & Uttarakhand & 2.86 & 0.63 & 0.78 & 0.58 \\
\hline 27. & $\begin{array}{l}\text { Uttar } \\
\text { Pradesh }\end{array}$ & 59.97 & 13.53 & 21.92 & 13.34 \\
\hline \multirow[t]{2}{*}{28.} & West Bengal & 35.93 & 4.29 & 4.96 & 10.82 \\
\hline & India & 501.76 & 140.84 & 92.81 & 91.25 \\
\hline
\end{tabular}

(IARI, 2012; Pathak et al., 2010; MNRE, 2009) 
Residue produced (\%)

(a)

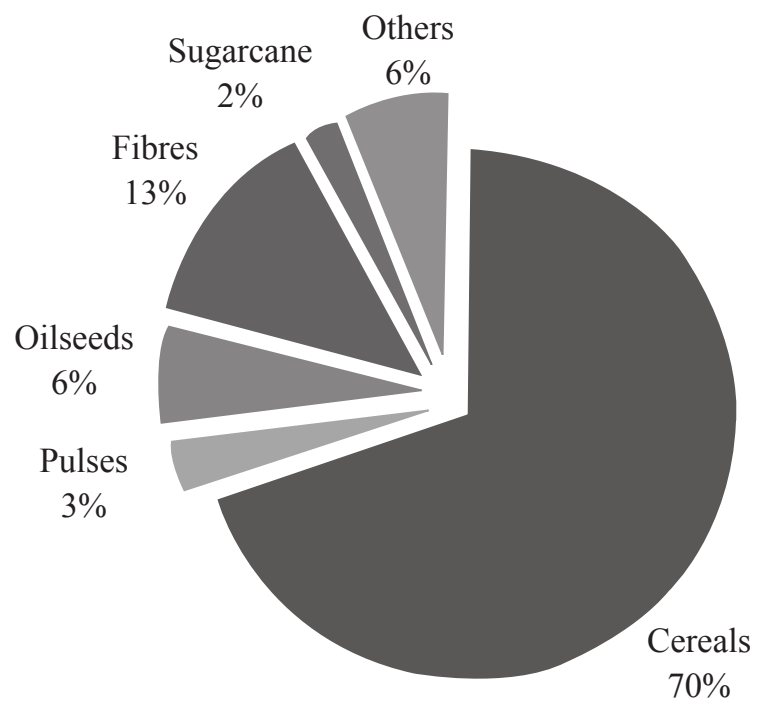

Unutilized residue (\%)

(b)

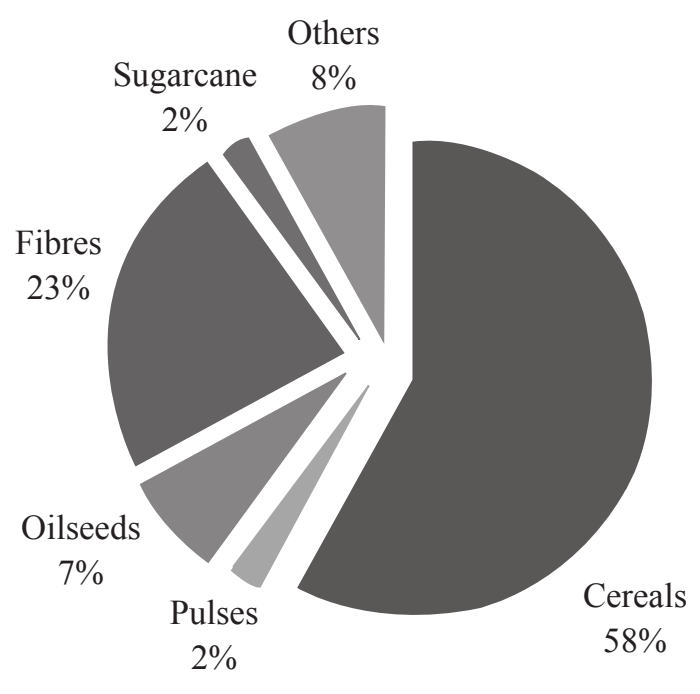

Figure 1: Contribution of various crops in residue generation and amount of surplus residue in India (IARI, 2012)

The major crops grown in these states are rice and wheat, which again indicate that rice and wheat residues are the major contributors of the total residue generated and burned. Significant contribution of rice and wheat in Indo-Gangetic plains during wheat and rice harvesting periods towards residue burning was also reported by Venkataraman et al. (2006) which is an important source of atmospheric pollution in this region. The amount of crop residues produced in 2001 was estimated about $4 \times 10^{9} \mathrm{t}^{\mathrm{tear}^{-1}}$ in the world (Lal, 2005 ). About $75 \%$ of the residues produced in the world and elsewhere is from cereals (e.g. corn, rice, wheat, sorghum, millet, barley, rye). Residue generation of five major cereals occupying large area in India calculated from predicted yield for the year 2011-12 by Government of India (Anonymous, 2013) and by using ratio of residue: economic yield given by Ministry of New and Renewable Resource, India (Table 2). On the basis of this estimate India is expected to harvest about $416.5 \mathrm{mt}$ of residue from five major cereals. Among them contribution of rice is highest $(177.34 \mathrm{mt})$ followed by wheat (169.02 mt).

\section{Options for Utilization of Generated Residue}

Crop residues have numerous competing uses that have made crop residue a precious commodity and must never be considered as a waste (Lal, 2004). The uses are mainly classified as on-farm and off-farm uses. Among on-farm uses, generated residue may be incorporated, retained on surface, burned in-situ or removed. Surface retention or incorporation may be complete or partial. This depends on the method of cultivation (Dormaar and Carefoot, 1996) and level of mechanization. Ploughing is the most efficient residue-incorporation method. Incorporation of rice residues before wheat planting is difficult due to low temperatures and the short interval between rice harvesting and wheat planting (Mandal et al., 2004). A field study conducted to evaluate the effects of crop residue incorporation in rice-wheat (RWCS) and rice-wheat-mung bean cropping systems (RWMCS) had revealed that after two years of continuous addition of residue in both the systems, 30.2 and $37.5 \mathrm{tha}^{-1}$ of total dry matter was added in RWCS and RWMCS, respectively (Table 3) (Dawari et al., 2012).

This incorporation of residue accounts for $188.9 \mathrm{~kg} \mathrm{~N} \mathrm{ha}^{-1}$, $20.4 \mathrm{~kg} \mathrm{Pha}^{-1}$ and $445.5 \mathrm{~kg} \mathrm{~K} \mathrm{ha}^{-1}$ to soil after two years which indicates the potential of crop residue to contributes for soil

Table 2: Predicted crop residue generation from major cereal by year 2011-2012 in India

\begin{tabular}{lcccc}
\hline Crop & $\begin{array}{c}\text { Total } \\
\text { production } \\
(\mathrm{mt})\end{array}$ & $\begin{array}{c}\text { Residue available } \\
\text { for 1 kg of crop }\end{array}$ & $\begin{array}{c}\text { Expected } \\
\text { crop } \\
\text { residue }\end{array}$ \\
\cline { 3 - 5 } & & $\begin{array}{c}\text { Straw/ } \\
\text { Stalk }\end{array}$ & $\begin{array}{c}\text { Husk/ } \\
\text { cob }\end{array}$ & $\begin{array}{c}\text { (million } \\
\text { tonnes) }\end{array}$ \\
\hline Rice & 104.3 & 1.5 & 0.2 & 177.34 \\
Wheat & 93.9 & 1.5 & 0.3 & 169.02 \\
Maize & 21.6 & 2.0 & 0.3 & 49.68 \\
Sorghum & 6.0 & 1.7 & $0.5+0.2$ & 14.4 \\
Pearl millet & 10.1 & 2.0 & $0.3+0.3$ & 6.06 \\
Total & & & & 416.5 \\
\hline
\end{tabular}

( ${ }^{1}$ Anonymous, $\left.2013 ;{ }^{2} \mathrm{MNER}, 2009\right)$ 
fertility and ultimately to sustainability. This incorporation also saves expenditure on fertilizer and increases profitability. While discussing causes and implication of residue burning in rice-wheat cropping system Gupta et al. (2004) considered in-situ incorporation being the best option for residue management in RWCS and suggested need for further research for fast decomposition of residue. The major disadvantage of incorporation of cereal straw is the immobilization of inorganic $\mathrm{N}$ and its adverse effect due to $\mathrm{N}$-deficiency (Mandal et al., 2004). Incorporation of rice straw into the soil after its harvesting leads slow down of decomposition and immobilisation of soil nitrate (Bacon, 1987), reduces the $\mathrm{N}$

Table 3: Total dry matter, organic carbon (C), total Kjeldahl'snitrogen $(\mathrm{N})$, total phosphorus $(\mathrm{P})$, and total potassium $(\mathrm{K})$ recycled through crop residue incorporation under different cropping systems during two years

\begin{tabular}{|c|c|c|c|c|c|}
\hline $\begin{array}{l}\text { Cropping } \\
\text { system }\end{array}$ & $\begin{array}{c}\text { Dry } \\
\text { matter } \\
\left(\mathrm{t} \mathrm{ha}^{-1}\right)\end{array}$ & $\begin{array}{l}\text { Carbon } \\
\left(\mathrm{t} \mathrm{ha}^{-1}\right)\end{array}$ & $\begin{array}{c}\text { Nitrogen } \\
\left(\mathrm{kg} \mathrm{ha}^{-1}\right)\end{array}$ & $\begin{array}{l}\text { Phos- } \\
\text { phorus } \\
\left(\mathrm{kg} \mathrm{ha}^{-1}\right)\end{array}$ & $\begin{array}{l}\text { Potas- } \\
\text { sium } \\
\left(\mathrm{kg} \mathrm{ha}^{-1}\right)\end{array}$ \\
\hline 2006-07 & & & & & \\
\hline $\begin{array}{l}\text { Rice-wheat } \\
\text { cropping } \\
\text { system }\end{array}$ & 14.2 & 5.7 & 61.7 & 8.5 & 213.1 \\
\hline $\begin{array}{l}\text { Rice-wheat- } \\
\text { mungbean } \\
\text { cropping } \\
\text { system }\end{array}$ & 17.8 & 7.1 & 114.9 & 12.4 & 228.7 \\
\hline $\begin{array}{l}\text { Mean } \\
2007-08\end{array}$ & 16.0 & 6.4 & 88.3 & 10.5 & 220.9 \\
\hline $\begin{array}{l}\text { Rice-wheat } \\
\text { cropping } \\
\text { system }\end{array}$ & 16.0 & 6.5 & 72.9 & 5.9 & 216.6 \\
\hline $\begin{array}{l}\text { Rice-wheat- } \\
\text { mungbean } \\
\text { cropping } \\
\text { system }\end{array}$ & 19.7 & 8.0 & 128.2 & 14.0 & 233.0 \\
\hline $\begin{array}{l}\text { Mean } \\
\text { Mean of } \\
\text { two-years }\end{array}$ & 17.9 & 7.3 & 100.6 & 11.8 & 224.8 \\
\hline $\begin{array}{l}\text { Rice-wheat } \\
\text { cropping } \\
\text { system }\end{array}$ & 30.2 & 12.2 & 143.6 & 14.4 & 429.7 \\
\hline $\begin{array}{l}\text { Rice-wheat- } \\
\text { mungbean } \\
\text { cropping } \\
\text { system }\end{array}$ & 37.5 & 15.1 & 243.1 & 26.4 & 461.7 \\
\hline Mean & 33.9 & 13.7 & 188.9 & 20.4 & 445.7 \\
\hline
\end{tabular}

uptake and yield of subsequent wheat crops by about $40 \%$ (Bacon, 1987; Sidhu and Beri, 1989).

Proper fertilizer management practices can reduce $\mathrm{N}$ immobilization due to incorporation of crop residues into the soil. These practices include appropriate method, time, and rate of fertilizer-N application: (i) placement of $\mathrm{N}$ fertilizer below the surface soil layer that is enriched with carbon after incorporation of crop residue, (ii) application of $\mathrm{N}$ fertilizer at a higher rate than the recommended rate, and (iii) application of $\mathrm{N} 15-20 \mathrm{~kg} \mathrm{ha}^{-1}$ as starter dose with straw incorporation increases yields of wheat and rice compared to either burning of straw or its incorporation in the soil (RWC-CIMMYT, 2003).

Besides incorporation, residue retention on the surface is another on-farm way for residue management. It came into force when concept of conservation agriculture started. Surface retention of residue is one of the important components among three components of conservation agriculture, viz., less disturbance to soil, surface retention of residue and crop rotation. Residue retention is also called as crop residue mulching (CRM) in zero tillage. Crop residue mulching can be defined as a technology whereby at the time of crop emergence at least $30 \%$ of the soil surface is covered by organic residue of the previous crop. CRM is distinguished from other mulching by its reliance on organic residue from previous crop (Erenstein, 1999). It is a dual-purpose technology that combines conservation and productivity effects. Its conservation potential hinges on the presence of the crop residues as mulch. This mulch provides a protective layer to the soil surface that is extremely effective in halting soil erosion and also amends the soil ecology. Its productivity potential is two-fold. First, the mulch tends to stabilise, and occasionally enhance crop yield. Second, it implies factor substitution and input use efficiency alterations (Erenstein, 2011).

Conservation effect of residue retention on soil reduces soil erosion due to its desirable impact on soil physical properties such as increasing infiltration and amount of water stable aggregate, decreasing bulk density (Reddy et al., 2002) and reducing runoff (Nalatwadmath et al., 2006). Potential of crop residue retention in declining erosion asymptotically to zero as cover increases (Erenstein, 2011) and almost elimination of soil erosion (Lal et al., 1990) was reported. The presence of crop residue mulch at the soil-atmosphere interface alters the entire soil ecology (Carsky et al., 1998). This is occurred through favourable effect of crop residue which provides a readily available source of food and creates a more favourable soil habitat (Carsky et al., 1998) which in turn favours the activity of soil biota. Influence of residue retention on crop yield is positive, negative or neutral depending on the factors of crop production which decide the contribution of retained 
residue towards crop yield.

Burning of residue is practised mainly in intensive cerealbased cropping system. The main reason for adoption of burning is less turn around period. Other reasons for burning includes land clearing, fertility enhancement, and weed/pest management; pasture management, hunting and personal wellbeing (Erenstein, 1999). Short-term increases in availability of some nutrients (e.g. P and K) reduce soil acidity and loss of other nutrients (e.g. N and S) and organic matter occurs due to residue burning (Akobundu, 1987). Loss of organic matter is one of the important threats to sustainability of intensive cereal-based cropping system such as rice-wheat cropping system (Timsina and Connor, 2001; Abrol et al., 2000) in India and its severity becomes more severe due to practice of residue burning.

In order to compare these three in-situ residue management practices i.e., incorporation, removal and burning for their capacity to influence soil physico-chemical properties, Bhat et al. (1991) conducted an experiment continuously for seven years and observed that after seven years organic carbon status of the soils was significantly increased when crop residues were incorporated compared to removal and burning. Similar was the trend for available and total forms of $\mathrm{N}, \mathrm{P}$ and $\mathrm{K}$ in soil (Table 4). All properties studied found better in incorporation followed by removal and burning.

In another study, the effect of rice residue management on grain and straw yield of wheat and succeeding rice crop showed that wheat grain yield was the highest when the residue was burnt and least when the residue was incorporated: however, but not differed significantly during the first year of study. In the second year, wheat grain yield was significantly higher after rice residue incorporation than removal and burning. In succeeding rice crop, in both the study years, grain and straw yields was slightly higher in plots where rice residue

Table 4: Effect of crop residue management for seven years in rice-wheat rotation on physico-chemical properties of the soil

\begin{tabular}{lccc}
\hline Property & \multicolumn{3}{c}{ Residue } \\
\cline { 2 - 4 } & Incorporated & Removed & Burned \\
\hline $\mathrm{pH}$ & 0.7 & 7.6 & 7.6 \\
$\mathrm{EC}\left(\mathrm{dSm}{ }^{-1}\right)$ & 0.75 & 0.13 & 0.13 \\
Organic C $(\%)$ & 154 & 139 & 0.59 \\
Available N $\left(\mathrm{kg} \mathrm{ha}^{-1}\right)$ & 45 & 38 & 32 \\
Available P $\left(\mathrm{kg} \mathrm{ha}^{-1}\right)$ & 85 & 56 & 77 \\
Available K $\left(\mathrm{kgha}^{-1}\right)$ & 2,501 & 2,002 & 1,725 \\
Total N $\left(\mathrm{kg} \mathrm{ha}^{-1}\right)$ & 1,346 & 924 & 858 \\
Total P $\left(\mathrm{kg} \mathrm{ha}^{-1}\right)$ & 40,480 & 34,540 & 38,280 \\
Total K $\left(\mathrm{kg} \mathrm{ha}^{-1}\right)$ & & &
\end{tabular}

was incorporated, although difference were not statistically significantly (Prasad et al., 1999).

Belling and removing of straw is the option selected when competitive uses are more economic than the insitu incorporation, retention or burning due to the fact that additional cost involved in belling and removal of straw. Though residue removed is used for variety of ways, it is mainly used for fodder and fuel purpose. Use of residue for composting is better substitution for in-situ retention of residue. This avoids the problems that arise due to retention such as immobilization of applied nitrogen. But again it involves cost and time to convert crop residue into compost. Residue use for energy generation is better than in-situ burning of crop residue. It also avoids problem of environmental pollution and gives energy for different uses. Residue can be used as bedding material for poultry birds, packing material for fruits and glass, etc. But to go for effective distribution of residue we need to have knowledge about which option generally farmers prefer.

\section{Criteria for Evaluating Residue Management Options}

In order to make and implement sound decision about the residue management it is necessary to scientifically understand the short and long term effects of different crop residue management practices and develop residue management technologies that provide agronomic benefits in a cost effective and environmentally acceptable manner. Singh et al. (2008) evaluated residue management options using criteria of productivity, profitability, environmental impact and sustainability of a cropping system. These criteria coincide with those used in approach of ecological intensification for intensive crop production system, which aims to satisfy the increasing demand for food, feed, fibre and fuel while meeting acceptable standards of environmental quality (Cassman, 1999; Witt, 2003).

\subsection{Productivity and profitability}

Productivity and profitability are the criteria directly related to farmers' decision making. Both criteria are the quantifiable indicators of short-term productivity. This includes grain yield, water and fertilizer-use efficiency and yield loss due to biotic stresses (disease, insect or weed pressure). Profitability indicator includes income from reduced input (such as labour, fertilizer, seed, machinery, irrigation water and pesticide). Residue management can differ in their effects on these indicators of productivity and profitability. So, in order to select appropriate option for residue management, residue associated changes for each indicator for different residue management practices need to be studied.

\subsection{Environmental impact and sustainability}

Environmental impact and sustainability are the criteria that are not typically important determinants for farmers in 
their selection of a particular residue management option, but these criteria can be important for policy-making such as banning of open field burning of crop residues. The main short-term environmental impact associated with residue management includes changes in air quality and greenhouse gas emission. Sustainability refers to medium and long-term ability of a residue management option to maintain or increase productivity and profitability of a cropping system. Indicators include the trends through time in yield, input- use efficiency, soil parameters (such as nitrogen-supply capacity, organic matter and potassium, sulfur and bulk density) and profitability.

\section{Factors Affecting Residue Management Options}

The variety of factors affect the selection of crop residue management options, which includes: (i) Type of crop: Crops varies in their chemical composition of residue. The characteristics like C: $\mathrm{N}$ ratio, lignin: $\mathrm{N}$ ratio, polyphenol and lignin content, etc. are important factors in deciding residue management option. (ii) Mehod of harvesting: Chances of residue retention will be less in manual harvest as most of the straw is removed for other uses in manual harvesting. On the other hand, chances for retention or burning are more in combine harvested crops. (iii) Turn around period: It is the period between harvesting of one crop and sowing of next crop. Less turn around period is one of the important reasons for burning of crop residue in rice-wheat cropping system. Gupta et al. (2004) attributed that a major constraint in a rice-wheat cropping system is the available short time between rice harvesting (late October and early November) and sowing of wheat (November). Given this short time, farmers find it difficult to utilise the residue and hence mostly opt for burning. (iv) Level of mechanization: It plays important role in increasing area under residue retention. Development of machinery for seeding in residue retained land leads to increase area under conservation agriculture. Field demonstration of 9-row happy seeder (HS) was carried out in different districts of Punjab from 2006-07 to 2009-10 (Sidhu et al., 2011). Based on the results from the demonstration trials, it was concluded that development of machinery plays important role in increasing area under surface retention. (v) Effect on next crop: This factor is important from the farmers' perspective. Farmers generally go for those options which have short-term positive impact on productivity of next crop. (vi) Agro-climatic condition: Residues of cereal crops such as sorghum (Sorghum bicolor L.) and pearl millet (Pennisetum glaucum L.) grown in dry land (sub-tropical and semi-arid) are removed for fodder and very less in remained for surface retention due to more competitive uses of residue in these area mostly as fodder. (vii) Other enterprises: Other enterprises have competitive interaction for residue. Increase in cattle population competes for residue and less in available for surface retention. Sometimes competitive interaction is beneficial as in case of in-situ burning and use of residue for energy generation. (viii) Awareness among farmers: Each option has both pros and cons. Information about these pros and cons to farmers plays important role in deciding management option for generated residues. Farmers are generally more aware about short-term impact; however they do not bother about long term impacts which have adverse effects on sustainability of farming system.

\section{Ecological Services of Residue Retention}

Retention of residue can be done differently such as either placed on surface or incorporated into soil. Placing residue on soil leads to heterogeneous distribution as it remains only on the surface while, incorporation leads to homogenous distribution (Singh et al., 2005). Heterogeneous distribution reduces the residue-soil contact as compared to a homogenous distribution. This distribution of residue has influence on the decomposition process.

The decomposition is affected by: (i) Crop residue: Size of residue has impact on the rate of decomposition. Smaller the size greater the rate, as smaller size increases area exposed for microbial activity and has better contact with soil particle. Since nitrogen content and C: $\mathrm{N}$ ratio influence decomposition. Legume residue decomposes faster than cereal residue. Lignin and poly-phenol decompose at slower rate and their content is higher in cereals which again reduce decomposition rate of cereals; (ii) Environmental Factors: Different environmental factors showed wide range of influence on rate of decomposition. Among them, temperature is important factor which creates difference in decomposition and ultimately carbon sequestration position in temperate and tropical regions. In temperate regions, rate of decomposition is less due to low temperature while it is high in tropical part of the world. As decomposition is faster in tropical part of the world there is higher potential for carbon sequestration. Temperature also affects decomposition rate indirectly through its influence on the growth and development of microbes, which carry out decomposition and affect physical and chemical factors responsible for decomposition. Soil water content is another edaphic factor affecting rate of decomposition. It affects microclimates which have strong influence on the microbial population and ultimately on rate of decomposition; (iii) Management Factors: Changes in decomposition process due to management factor are mainly related to changes in the tillage system. Variation in tillage creates variation in all physical, chemical and biological parameters of soil which ultimately affects the rate of decomposition.

There are numerous ecosystem services of residue retention 
on cropland, especially if maintained as surface mulch. Onsite, residues retention improves soil physical (e.g. structure, infiltration rate, plant available water capacity), chemical (e.g. nutrient cycling, cation-exchange capacity, soil reaction), and biological (e.g. soil organic carbon sequestration, microbial biomass carbon, activity and species diversity of soil biota) quality. Residue acts as mulchis effective against soil erosion and water losses by surface runoff and evaporation. Consequently, agronomic productivity and profitability are high with use of crop residues in conjunction with no-tillage in conservation agriculture. Raddy et al. (2002) studied the effect of crop residue and tillage operation on the physical properties of soil. They observed that application of wheat straw $\left(5 \mathrm{t} \mathrm{ha}^{-1}\right)$ reduced the bulk density and increased infiltration rate significantly over control. A water stable aggregate were higher in same treatment but not significant over control. Nalatwadmath et al. (2006) conducted field experiment in sorghum + Dolichos intercropping system for four years in winter (rabi) season and they observed that treatment containing sorghum + Dolichos (cut at 45 DAS and incorporated) recorded lowest runoff and reduce the soil loss by $1,189 \mathrm{~kg} \mathrm{ha}^{-1}$ compared to control $\left(4,940 \mathrm{~kg} \mathrm{ha}^{-1}\right)$. Positive effect of crop residue on physical properties like bulk density, porosity, water sorptivity and aggregation was also reported by Shaver (2010) after conducting experiment involving study of effect of crop residue on these properties after 12 years in dry land of eastern Colorado.

Improvement in soil physical properties and reduction in runoff and soil losses lead to favourable effect on moisture conservation. All these factors lead to increase in yield of crops especially seen in dry-land areas. Thakur et al. (2011) reported that wheat straw mulch@6 tha-1 resulted in significantly higher yield than no mulch in two years of study. Combined analysis of data regarding residue management from 31 experiments on effect of incorporating rice and upland crop residue on the yield of following rice crop revealed no significant trend of increasing yield due to residue incorporation. Residue of wheat incorporated into rice also did not have a residual effect on wheat crop that followed rice (Singh et al., 2008).

Among chemical properties, soil organic carbon is important factor which have strong influence on the all soil properties. Soil carbon content was strongly affected by the options of residue management such as incorporation, burning and removal. Prasad et al. (1999) reported increased carbon content $(0.61 \%)$ due to straw incorporation compared with that of straw removal $(0.53 \%)$ of wheat in succeeding rice crop. Dhiman et al. (2000) also showed that incorporation of rice straw in succeeding wheat crop increases soil carbon content $(0.86 \%)$ compared to removal $(0.51 \%)$. Addition of crop residue to soil is also an avenue for carbon sequestration. Jacinthe et al. (2002) observed that fertilization of wheat residues with $\mathrm{N}$ increased humification of biomass and enhanced the carbon sequestration rate of the soil in central Ohio, USA. Residue management also affects weed population.

Among off-site advantages, mulch farming through residues retention and a no tillage system improve quality of water and air through reduction in erosion (water and wind), non-point source pollution, sedimentation, and transport of pollutants into the water bodies and aquatic ecosystems. Further, reduction in frequency and intensity of floods causes minimal damages to infrastructure (e.g. highways, bridges, waterways) and tourism. Productivity of aquaculture and agricultural systems in the flood plains is improved because of less runoff of water, sediments and pollutants. Thus retention of residues promotes sustainable land use because of positive impacts on the environment and ecosystem services.

\section{Residue Burning and Removal}

Residue burning is generally practiced in intensive cerealbased cropping system such as in rice-wheat cropping system. Main reasons for burning of crop residue is less turn-around time which makes difficult to either remove or incorporate the residue. In this situation burning of crop residue is cheap and less time-consuming option which completely cleans the field for carrying out other operations. Retention of residue interferes with the sowing operation of the next crop. It sometimes also makes difficulty in the emergence of next crop. In order to avoid these problems, farmers go for burning. Other reason for burning includes immobilization of nitrogen due to wider $\mathrm{C}: \mathrm{N}$ ratio of crop residue. An incorporation of cereal straws of wide $\mathrm{C}: \mathrm{N}$ ratio immobilizes soil nitrogen and adversely affects the yield of the succeeding crop (Sidhu and Beri, 1989). This immobilization reflects in lower yield in residueretained plots compared to residue removed or burned plots if the nitrogen level in the field was low and less nitrogen added through fertilizer. There are varieties of adverse impact of residue burning. Due to burning of residue, heat from burning residues elevates soil temperature causing death of bacterial and fungal populations. However, the death is temporary as the microbes regenerate after few days. Repeated burning in the field, however, permanently diminishes the microbial population. Burning immediately increases the exchangeable $\mathrm{NH}_{4}^{+}-\mathrm{N}$ and bicarbonate extractable $\mathrm{P}$ content but there is no build up of nutrients in the profile. Long-term burning reduces total $\mathrm{N}$ and $\mathrm{C}$ and potentially mineralized $\mathrm{N}$ in the $0-15 \mathrm{~cm}$ soil layer. Burning of residue causes large losses of nutrient such as $\mathrm{N}$ up to $80 \%$ (Raison, 1979), phosphorus $25 \%$, potassium 21\% (Ponnamperuma, 1984) and sulphur 4.6\% (Lefroy et al., 1994). Burning of residues also elevates the environmental 
problems such as emission of significant amount of greenhouse gases. For example, 70,7 and $0.66 \%$ of $\mathrm{C}$ present in rice straw is emitted as $\mathrm{CO}_{2}, \mathrm{CO}$ and $\mathrm{CH}_{4}$, respectively, while $2.09 \%$ of $\mathrm{N}$ in straw is emitted as $\mathrm{N}_{2} \mathrm{O}$ upon burning (Pathak et al., 2011).

Burning of agricultural residues causes a significant source of chemically and radiatively important trace gases and aerosols such as $\mathrm{CH}_{4}, \mathrm{CO}, \mathrm{N}_{2} \mathrm{O}, \mathrm{NO}_{\mathrm{X}}$ and other hydrocarbons to the atmosphere affecting the atmospheric composition. It also emits large amount of particulates that are composed of wide variety of organic and inorganic species. Besides other light hydrocarbons, volatile organic compounds (VOCs) and semivolatile organic compounds (SVOCs) including polycyclic aromatic hydrocarbons (PAHs) and polychlorinated biphenyls (PCBs) and $\mathrm{SO}_{x}, \mathrm{NO}_{x}$ are also emitted. These gases are important for their global impact and may lead to a regional increase in the levels of aerosols, acid deposition, increase in tropospheric ozone and depletion of the stratospheric ozone layer. Many of the pollutants found in large quantities in biomass smoke are known or suspected carcinogens and could be a major cause of concern leading to various air borne lung diseases. Emissions from the burning of fossil fuels and biomass have led to the creation of atmospheric brown clouds of black carbon and aerosols in various parts of the world (Auffhammer et al., 2006); Long et al. (1998) studied the health consequences from burning of agricultural residue. They surveyed 428 participants with underlying respiratory disorders and exposure to pollution from burning of agricultural residues. They found that people with underlying respiratory disorders were susceptible to the air pollution caused by burning of agricultural residue. Singh et al. (2008) summarized the work of four studies conducted to find out the effect of residue management on emission of greenhouse gases $\left(\mathrm{CH}_{4}\right.$ and $\left.\mathrm{N}_{2} \mathrm{O}\right)$. They studied different factors affecting residue management and their impact on the emission of methane and nitrous oxide and concluded that, removal of residue and minimum flooding is best practice to reduce methane emission, while continuous flooding is best to reduce nitrous oxide emission from rice field.

Agronomists and soil scientists, in view of numerous ecosystem services of residues retention, argue that there is no such thing as free bio-fuels from crop residues (Lal, 2007; Lal and Pimental, 2007). There are numerous direct and indirect adverse impacts of residue removal on ecosystem services, including depletion of the soil organic carbon pool. Important among direct impacts of residue removal are low input of biomass $\mathrm{C}$, reduction in nutrient cycling, decrease in food/ energy source and habitat for soil biota along with decline in soil quality. There are also numerous indirect impacts of residue removal. Notable among these are: increase in risks of soil erosion and runoff because of decrease in aggregation and increase in soil susceptibility to crusting and compaction. The loss of water and nutrients from the ecosystems also decreases crop growth and yield and reduces agronomic productivity. Mann et al. (2002) argued that more research is needed on several topics to determine potential long-term effects of residue harvest, including (i) erosion and water quality, especially pesticides and nitrates, (ii) rates of transformation of different forms of soil organic carbon, (iii) effects on soil biota, and (iv) soil organic carbon dynamics in subsoil. The innovations such as resources conservation technologies in residue management avoid straw burning, improve soil organic carbon, enhance input-use efficiency and have potential to reduce greenhouse gases (GHG) emission (Pathak et al., 2011).

\section{Residue: an Energy Source}

The use of crop residue as a source of energy is of interest worldwide because of its environmental advantages. It has two other main advantages: firstly it is a renewable and secondly it can be used without essential damage to the environment (Nendel et al., 1998). As residue contains high amount of carbon, it assimilates a large amount of solar energy. Energy equivalent of crop residues is estimated at about $18.6 \times 10^{9}$ $\mathrm{J} \mathrm{t}^{-1}$ dry biomass (Weisz, 2004). It is because of its highenergy value, the crop residues as bio-fuels are considered an alternative to fossil fuel (Somerville, 2006). There are some examples in India regarding residue is used for energy generation on large scale. Kalpataru Power Transmission Limited (KPTL), a leading global engineering, procurement and construction player in power sector, is successfully generating energy from crop residues in Ganga nagar and Tonk districts of the Indian state of Rajasthan for the past several years. At Tonk, the plant utilizes 80,000 t of biomass annually, mostly from mustard crop, and generates 1.5 lakh $\mathrm{k}$ Wh energy day $^{-1}$ (IARI, 2012).

There are varieties of options available for conversation of crop residue into useful energy products. These include the conversion of ligno-cellulosic biomass into bio-based alcohol production. This can be either blended with gasoline as a fuel extender and octane-enhancing agent, or used as a neat fuel in internal combustion engines. Thermo-chemical conversation of crop residue can be done by various ways. Pyrolysis is one among them. It may be fast or slow pyrolysis. Fast pyrolysis requires temperature of biomass to be raised to $400-500{ }^{\circ} \mathrm{C}$ within a few seconds, resulting in a remarkable change in the thermal disintegration process. About $75 \%$ of dry weight of biomass is converted into condensable vapours. If the 
condensate is cooled quickly within a couple of seconds, it yields a dark brown viscous liquid commonly called bio-oil. The calorific value of bio-oil is $16-20 \mathrm{MJ} \mathrm{kg}^{-1}$. Slow pyrolysis on other hand leads to form bio-char. Bio-char is a high carbon material produced through slow pyrolysis (heating in the absence of oxygen) of biomass. It is a fine-grained charcoal and can potentially play a major role in the long-term storage of carbon in soil.

Other process is gasification which leads formation of gas due to partial combustion of crop residues. The main problem in biomass gasification for power generation is the purification of gas for removal of impurities. The crop residues can be used in the gasifiers for 'producer gas' generation. Biomethanation is a well known process which leads to formation of bio-gas. Methane $\left(\mathrm{CH}_{4}\right)$ and carbon-dioxide $\left(\mathrm{CO}_{2}\right)$ are the major gases in biogas. It is a non-destructive way to extract high quality fuel gas and produce manure to be recycled in soil. Crop residue can also be used for generation of heat through the process of combustion. Crop residue also plays an important role in efficient utilization of energy in crop production which leads to energy efficient farming system (Lal, 1995, 2009). Addition of crop residue adds some amount of nutrient, suppresses the weed population and reduces tillage. This leads to saving energy on fertilizer, herbicide and fuel for tillage. All these contribute directly to energy saving. On the other hand, increase in production and income stability has indirect contribution to energy saving. At the same time, both direct and indirect ways are environmentally compatible ways for energy saving.

\section{Residue Management for Dryland Agriculture}

The paradox situation in crop residue management exists in Indian condition. On one hand, we are talking about air pollution due to residue burning over large area and on other hand, we are facing scarcity of fodder as the residue available is not sufficient to meet fodder requirement of milking and drought animals in dry land agriculture. In dry land area, there are varieties of competitive uses of crop residue which leads to no or very less surplus residue to keep on land. Due to this reason some states have higher residue-generation with less amount of burned residue. This competitive uses of crop residue make it economic product and sell in market like main crop produce.

In these areas water content of soil is the deciding factor for decomposition of crop residue. Residue retention was effectively practiced in intercropping system where one component crop matures earlier than other. Mid-season drought during growing season is one of the main causes for low yield of rain-fed sorghum. Moisture conservation in soil and reduction in soil erosion can be achieved by use of crop residue as mulch (Thakur et al., 2011). This increased moisture-storage capacity of soil and prolong the duration of moisture available for sowing winter (rabi) season crop under dry-land condition. Adverse effect of extreme event of rainfall can be minimized due to residue retention.

\section{Impact of Residue Management on Environment}

Amount of crop residue added to the soil some of that during mineralization converted into $\mathrm{CO}_{2}$ and emitted into atmosphere. Decomposition of residue also leads methane $\left(\mathrm{CH}_{4}\right)$ formation when it decomposed under anaerobic condition and diffused into atmosphere. Remaining part is stored in micro-aggregation and organo-mineral complexes. Carbon storage in deep horizons is not readily mineralized and leads to less emission and less risk of erosion (Lal, 1995). This increased carbon content in soil has positive impact on biomass production which again increases carbon addition in soil.

\section{Residue Management: Research, Development and Policy Needs}

For effective utilization and appropriate distribution of crop residue among various options of residue management there is need to priorities some research, development and policy needs. Some of the research (Singh et al., 2005; Prasad and Power, 1991), and policy and development needs (MNRE, 2009; IARI, 2012) are given below:

\subsection{Research needs}

- Evolution of crops in terms of residue production, decomposition and nutrient retention.

- Characterization of crop residues for their chemical composition that help to prepare a database of residue quality.

- Information needs to be collected on the effect of management on decomposition, nutrient release rates and production of phototoxic compounds from crop residue.

- There is need to indentify some robust plant indices that provides improved prediction of nutrient release and soil organic matter formation.

- Estimate of relative cost of different options must be developed.

- Study the effect of crop-residue management practices on secondary and micronutrients of soil and their availability to crop.

- To develop suitable computer simulations to predict the effects of number of factors on soil properties and finally on crop growth and yield. 
- Quantification and putting a price tag on non-monitory benefits from residue to ecosystem is needed.

\subsection{Policy and development needs}

- Developing and implementing appropriate legislation on prevention and monitoring of on-farm residue burning.

- Supplying machineries on subsidized rates and providing soft loans for purchase of implements.

- Introduction of carbon credit schemes to benefit the farmers.

- Establishing self-help group and encouraging unemployed youths to take up custom-hiring of conservation agricultural machineries as a profession.

- Familiarizing different residue-management technologies for awareness generation among farmer.

\section{Model Plan For Managing Residue}

As the generation, demand, quality, feasibility and economics of crop residue management vary from region to region, a region-specific and need-based crop residues management plan should be laid. Scientist at IARI (2012) prepared a model plan (Table 5) which may be used as a guideline for managing crop residues at local and regional scales.

\section{Conclusion}

From the foregoing discussion it can be concluded that cereal residue has a potential to emerge as a one of important sources of nutrient owing to availability in huge amount. It also plays important role in improving soil physical, chemical and biological properties over long-run and thereby sustaining production system and eco-services. Use of surplus residue for energy generation instead of on-farm burning is a better option to cope up with increased air pollution due to residue burning. Balanced distribution and efficient utilization of cereal residues are compelled us to say 'cereal residues are not waste until we waste it!'

\section{References}

Abrol, I.P., Bronson, K.F., Duxbury, J.M., Gupta, R.K., 2000. Analysis of long-term soil fertility experiments in ricewheat cropping systems. Rice-Wheat Consortium Paper Series 6. RWC and CIMMYT, New Delhi, India.

Akobundu, I.O., 1987. Weed Science in the Tropics: Principles and Practices. Wiley, Chichester.

Anonymous. 2013. Statistical appendix, Economic survey of India. http://indiabudget.nic.in/survey.asp.

\begin{tabular}{|c|c|c|c|}
\hline $\begin{array}{l}\text { Sl. } \\
\text { no. }\end{array}$ & Query & Response & Crop residue management options \\
\hline 1. & $\begin{array}{l}\text { Can crop residues be used for conservation agricul- } \\
\text { ture? } \\
\text { (If answer is 'No', than move to the next query ) }\end{array}$ & Yes & $\begin{array}{l}\text { - Retain it on soil surface } \\
\text { - Use drill (Happy seeder) for sowing with residues } \\
\text { - Follow conservation agriculture for maximum } \\
\text { numbers of crops }\end{array}$ \\
\hline 2. & Can it be used as a fodder? & Yes & $\begin{array}{l}\text { - Leave the stubble on the field } \\
\text { - Use manure in same field }\end{array}$ \\
\hline 3. & Can it be used for biogas generation? & Yes & $\begin{array}{l}\text { - Leave the stubble on the field } \\
\text { - Use slurry in field }\end{array}$ \\
\hline 4. & Can it be used for composting? & Yes & $\begin{array}{l}\text { - Leave the stubble on the field } \\
\text { - Use compost in same field } \\
\text { - Adopt modern composting technique }\end{array}$ \\
\hline 5. & Can crop residues be used for bio-fuel generation? & Yes & $\begin{array}{l}\text { - Leave the stubble on the field } \\
\text { - Install bio-fuel plant } \\
\text { - Use liquid slurry in field }\end{array}$ \\
\hline 6. & Can it be used for electricity generation? & Yes & $\begin{array}{l}\text { - Use ash in conservation agriculture } \\
\text { - Leave the stubble on the field }\end{array}$ \\
\hline 7. & Can it be used for gasification? & Yes & $\begin{array}{l}\text { - Leave the stubble on the field } \\
\text { - Use ash in field }\end{array}$ \\
\hline 8. & Can it be used for gasification or bio-char making? & Yes & $\begin{array}{l}\text { - Use bio-char in same field } \\
\text { - Leave the stubble on the field } \\
\text { - Use ash in same field. }\end{array}$ \\
\hline
\end{tabular}


Auffhammer, M., Ramanathan, V., Vincent, J. 2006. Integrated model shows that atmospheric brown clouds and greenhouse gases have reduced rice harvests in India. Proceedings of the National Academy of Sciences 103(52), 19668-19672.

Bacon, P.E., 1987. Effect of nitrogen fertilization and rice stubble management techniques on soil moisture content, soil nitrogen status, and nitrogen uptake by wheat. Field Crops Research 17, 75-90.

Beri, V., Sidhu, B.S., Bahl, G.S., 2002. Crop residue management. In: Recent Advances in Agronomy, Indian Society of Agronomy, Indian Agricultural Research Institute, New Delhi, India.

Bhat, A.K., Beri, V., Sidhu, B.S., 1991. Effect of long-term recycling of crop residues on soil productivity. Journal of the Indian Society of Soil Science 39, 380-382.

Carsky, J.R., Hayashi, Y., Tian, G., 1998. Benefits of mulching in the sub-humid savannah zone: research needs and technology targeting. Draft Resource and Crop Management Research Monograph. IITA, Ibadan, Nigeria.

Cassman, K.G., 1999. Ecological intensification of cereal production system: yield, potential, soil quality and precision agriculture. In: Academy of Sciences Colloquium; "Plant and population: Is there time?" Proceedings of the National Academy of Agricultural Sciences, USA 96(11), 5952-5959.

Davari, M.R., Sharma, S.N., Mirzakhani, M., 2012. Effect of cropping systems and crop residue incorporation on production and properties of soil in an organic agro ecosystem. Biological Agriculture and Horticulture: International Journal of Sustainable Production Systems 28(3), 206-222.

Dhiman, S.D., Nandal, D.P., Om, H., 2000. Productivity of rice-wheat cropping system as affected by its residue management and fertility levels. Indian Journal of Agronomy 45(1), 1-5.

Dormaar, J.F., Carefoot, J.M., 1996. Implications of crop residue management and conservation tillage on soil organic matter. Canadian Journal of Plant Science 76, 627-634.

Erenstein, O., 1999. Conservation farming and small-scale farmers: lessons and opportunities for mulching with crop residues and cover crops. Consultancy Report Rural Development Department of World Bank, Washington, DC.

Erenstein, O., 2002. Crop residue mulching in tropical and semi-tropical countries: An evaluation of residue availability and other technological implications. Soil and Tillage Research 67, 115-133.

Erenstein, O., 2011. Cropping system and crop residue management in the Trans-Gangetic Plains: Issues and challenges for conservation agriculture from village surveys. Agricultural Systems 104, 54-62.

Gupta, P.K., Sahai, S., Singh, N., Dixit, C.K., Singh, P.D., Sharma, C., Tiwari, M.K., Gupta, R.K., Garg, S.C., 2004. Residue burning in rice-wheat cropping system: Causes and implications. Current Science 87(12), 1713-1717.

IARI. 2012. Crop residue management with conservation agriculture: Potential, constraints and policy needs. Indian agricultural research institute, New Delhi, India,1-3.

Jacinthe, P.A., Lal, R., Kimble, J.M., 2002. Effects of wheat residue fertilization on accumulation and biochemical attributes of organic carbon in a central Ohio Luvisol. Soil Science 167, 750-758.

Lal, R., 2009. Crop residues and soil carbon. http://www.fao. org/ carbonmeeting/3full papers by consultationspeakers/ paperlal.pdf.

Lal, R., 1995. The role of residue management in sustainable agriculture. Journal of Sustainable Agriculture 5(4), 5178.

Lal, R., 2004. Is crop residue a waste? Journal of Soil and Water Conservation 59, 136-139.

Lal, R., 2005. World crop residues production and implication of its use as a biofuel. Environment International 31, 575586.

Lal, R., 2007. There is no such thing as a free biofuel from crop residues. CSA News 52(5), 12-13.

Lal, R., 2008. Crop residues as soil amendments and feedstock for bioethanol production. Waste Management 28, 747758.

Lal, R., Eckert, D.J., Fausey, N.R., Edwards, W.M., 1990. Conservation tillage in sustainable agriculture. In: Sustainable Agricultural Systems, Edwards, C.A., Lal, R., Madden, P., Miller, R.H., House, G. (Eds), Soil and Water Conservation Society, Iowa, 203-225.

Lal, R., Kimble, J.M., 2002. Conservation tillage: Prospects for the future. In: Proceedings of the International Conference on Managing Natural Resources for Sustainable Agricultural Production in the $21^{\text {st }}$ Century (Invited Papers), 14-18 February, 116-125.

Lal, R., Pimentel, D. 2007. Biofuels from crop residues. Soil and Tillage Research 93, 237-238.

Lefroy, R.D.B., Chaitep, W., Blair, G.J., 1994. Release of sulphur from rice residue under flooded and non-flooded soil conditions. Australian Journal of Agricultural Research 45, 657-667.

Long, W., Tate, R., Neuman, M., Manfreda, J., Becker, A., Anthonisen, N., 1998. Respiratory symptoms in a susceptible population due to burning of agricultural residue. Chest 113(2), 351-357.

Mandal, K.G., Misra, A.K., Hati, K.M., Bandyopadhyay, K.K., Ghosh, P.K., Mohanty, M., 2004. Rice residuemanagement options and effects on soil properties and 
crop productivity. Food, Agriculture and Environment 2(1), 224-23.

Mann, L., Tolbert, V., Cushman, J., 2002. Potential environmental effects of corn (Zea mays L.) stover removal on soil organic matter and erosion. Agriculture, Ecosystems and Environment 89, 149-166.

MNRE. 2009. Ministry of new and renewable energy resources, Government of India, www.mnre.gov.in/ biomass resources.

NAAS. 2012. Management of crop residues in the context of conservation agriculture". Policy Paper No. 58, National Academy of Agricultural Sciences, New Delhi, 12.

Nalatwadmath, S.K., Patil, S.L., Adhikari, R.N., Mana Mohan, S., 2006. Effect of crop residue management on soil erosion, moisture conservation, soil properties and sorghum yield on vertisols under dryland condition of semi-arid tropics in India. Indian Journal of Dryland Agricultural Research and Development 21(2), 99-104.

Nendel, K., Clau, B., Bottger, U., 1998. The pre-conditioning of biomass by briquetting technology and the influence on the combustion behaviour. In: The $10^{\text {th }}$ European Conference on Biomass for Energy and industry, June 1998, Würzburg, Germany.

Pathak, B.S., 2004. Crop residue to energy. In: Environment and Agriculture, Chadha, K.L., Swaminathan, M.S. (Eds), Malhotra Publishing House, New Delhi, 854-869.

Pathak, H., Bhatia, A., Jain, N., 2010. Inventory of greenhouse gas emission from agriculture. Report submitted to Ministry of Environment and Forests, Govt. of India.

Pathak, H., Saharawat, Y.S., Gathala, M., Ladha, J.K., 2011. Impact of resource-conserving technologies in the rice-wheat system. Greenhouse Gases: Science and Technology 1, 261-277.

Ponnamperuma, F.N., 1984. Straw as a source of nutrients for wetland rice. In: Organic Matter and Rice, Banta, S., Mendoza, C.V., (Eds), IRRI, Los Banos, Philippines, 117136.

Prasad, R., Ganagiah, B., Aipe, K.C., 1999. Effect of crop residue management in rice-wheat cropping system on growth and yield of crops and on soil fertility. Experimental Agriculture 35, 427-435.

Prasad, R., Power, J.F., 1991. Crop residue management. Advances in Soil Science 15, 205-25.

Rabbinge, R., van Ittersum, M.K., 1994. Tension between aggregation levels. In: The Future of the Land: Mobilising and Integrating Knowledge for Land Use Options, Fresco, L.O., Stroosnijder, L., Bouma, J., Keulen, H.V., (Eds.), Wiley, Chichester, 31-40.

Raison, R.J., 1979. Modification of the soil environment by vegetation fires, with particular reference to nitrogen transformation: A review. Plant and Soil 51, 73-108.
Reddy, G.R., Malewar, G.U., Karle, B.G., 2002. Effect of crop residue incorporation and tillage operations on soil properties of vertisol under rain-fed agriculture. Indian Journal of Dryland Agricultural Research and Development 17(1), 55-58.

RWC-CIMMYT. 2003. Addressing Resource Conservation Issues in Rice-Wheat Systems of South Asia: A Resource Book. Rice-Wheat Consortium for the Indo-Gangetic Plains-International Maize and Wheat Improvement Centre, New Delhi, India.

Shaver, T., 2010. Crop residue and soil physical properties. In: Proceedings of $22^{\text {nd }}$ annual central plain irrigation conference, 24-25 February, 2010, Kearney, US.

Sidhu, B.S., Beri, V., 1989. Effect of crop residue management on the yields of different crops and on soil properties. Biological Wastes 27, 15-27.

Sidhu, H.S., Singh, M., Singh, Y., Blackwell, J., Singh, V., Gupta, N., 2011. Machinery development for crop residue management under direct drilling. http://aciar. gov.au/files/node/13991/machinery_development_for_ crop_residue_management_13112.pdf.

Singh, B., Shan, Y.H., Beebout, J., Singh, Y., Buresh, R.J., 2008. Crop residue management for lowland rice-based cropping systems in Asia. Advances in Agronomy 98, 117-199.

Singh, Y., Singh, B., Timsina, J., 2005. Crop residue management for nutrient cycling and improved soil productivity in rice-based cropping systems in the tropics. Advances in Agronomy 85, 269-407.

Somerville, C., 2006. The billion-ton biofuel vision. Science 312, 1277.

Thakur, N.S., Kushwaha, B.B., Sinha, N.K., 2011. Productivity and water use in kharif sorghum (Sorghum bicolor) under different land configuration and mulching. Indian Journal of Agronomy 56(1), 47-51.

Timsina, J.D., Connor, D.J., 2001. Productivity and management of rice-wheat cropping system: Issues and Challenges. Field Crops Research 69, 93-132.

Venkataraman, C., Habib, G., Kadamba, D., Shrivastava, M., Leon, J., Crouzille, B., Boucher, O., Streets, D., 2006. Emissions from open biomass burning in India: Integrating the inventory approach with high-resolution Moderate Resolution Imaging Spectroradiometer (MODIS) active fire and land cover data. Global Biogeochemical Cycles 20(2), DOI: 10.1029/2005GB002547.

Weisz, P.B., 2004. Basic choices and constraints in long-term energy supplies. Physics Today 57, 47-52.

Witt, C., 2003. Fertilizer use efficiencies in irrigated rice in Asia. In: International fertilizer association regional conference for Asia and pacific, Cheju Island, Republic of Korea, 6-8 October, 2003 (www.fertilizer.org/ifa/publicate/pdf). 